відповідальною за сприяння модернізації суспільства та виховання свідомої громадянської позиції суб‘єктів суспільної діяльності.

\title{
Анотації
}

У статті А.Сабадуха «Думки фрілософрів і християнських авторів про Церкву...» анотуються думки деяких з означених мислителів про роль та значення Церкви в житті суспільства. Проаналізовано зокрема проблему відповідальності українських християнських Церков за формування почуття відповідальності в умовах розбудови громадянського суспільства в Україні.

В статье А.Сабадуха «Мысли философов и христианских авторов о Церкви...» аннотируются взгляды некоторых мыслителей на роль и значение Церкви в жизни общества. Рассмотрена проблема ответственности украинских христианских Церквей за формирование чувства ответственности в условиях построения гражданского общества в Украине.

Sabaducha O. V. Investigated role and importance of church in the life of society. Analyzed problem of responsibility of Ukrainian Christian Church for creating sense of responsibility in conditions of building civil society in Ukraine. Proved that the church should be responsible for education and breeding of subject of activity with conscientious citizenship.

\section{М.Яркіна (Київ)}

\section{СВІТОГЛЯДНА СКЛАДОВА ТРАНСФОРМАЦІЇ СИМВОЛІВ}

3 багатьох проблем історії та культури проблема правильного розуміння та тлумачення універсальних символів, а також їх розумного використання, $\epsilon$ досить актуальною. Оскільки предметом дослідження $є$ не окремі символи і навіть не символічні системи, а світоглядна складова трансформації символів, то у сфері дослідження опиняється взаємодія культури і ії творця - людини, зміна позиції яких веде до зміни інтерпретації символів, а тому й зміни символіки. Основним завданням статті ми вбачаємо осмислення феномену символу та його трансформації в єдиній структурі історії та культури.

Символ, як вияв глибинної народної культури та світогляду, як концентрат цінностей багатьох народів, може бути об'єктом філософського аналізу. В цьому унікальному феномені культури досить гармонійно сходяться три історичні типи світогляду: міфологічний, релігійний та філософський. Адже міфологія, як образне мислення, якнайтісніше пов'язана з емоційним пізнанням i переживанням дійсності. Міф усе оживляє, одушевляє, він наповнений чудесним і чарівним. Міф, будучи синкретичним, містить у собі елементи релігійних вірувань і художнього уявлення, а також зачатки раціонального, 
однак при цьому не є якимсь видом релігії, мистецтва чи знання. Міф як світосприймання є витвором суб'єктивної реальності, але такої, що сприймається як справжня. Міф слугує не для пояснення чогось, а для виправдання певних "священних" установок, тобто санкціонування певної свідомості та поведінки. Символ, як художньо-релігійна структура, безумовно, виникає в лоні міфологічного світогляду і більше того - в найбільш ранніх формах первісного мислення, в якому виникає певна система знаків, яка утворює заборони, тотеми чи табу. Тут спільність між символом та знаком особливо яскраво проявляється в їхньому суттєвому означенні: вони є виявом таємного, прихованого змісту, який $є$ доступним лише вузькому колу посвячених.

Міфологія і релігія тісно пов'язані між собою. Образне мислення передбачає світовідчуття, світопереживання і стає провідником до релігійності. Адже релігія - це особлива форма суспільної свідомості, яка по-своєму прагне пронизувати всі інші форми свідомості. Вона по-своєму відображає великий життєвий досвід людства, систему емоційно-образних уявлень і переживань, вартостей, норм життя, моральних ідеалів. Релігія культивує такі високі гуманістичні норми, як віра, любов, добро, терпимість, співчуття, милосердя, почуття обов'язку, справедливості. А це все отримує яскраве вираження в символіці. Міфологічний та релігійний світогляд не стоїть осторонь філософського. Філософський світогляд у цьому разі, по суті, узагальнює ці два попередні i зосереджує увагу на онтологічному, гносеологічному та аксіологічному аспекті символіки.

Якщо зупинитися зокрема на онтологічному аспекті символіки, то ця сфера перш за все пов'язана як з духовною, так і з матеріальною реальністю, а відтак видимою природою, де символ виступає як знак, та невидимою, де він постає як носій духовності. Гносеологія ж символів дає цікаві приклади тлумачення і розуміння головних проблем життя та ролі духовності в його вдосконаленні. У сфері ж аксіології йдеться звичайно про знання, переживання цінностей, як загальнолюдських, так і вузьконаціональних. Саме ціннісний характер значення символів відрізняе його від всіх інших видів знаків чи емблем, від образотворчих, або іконічних, знаків, від алегоричних знакових структур та ін. Всі ці знаки, функціонуючи, в своєму прямому призначенні, несуть інформацію суто понятійного, смислового, але не ціннісного характеру. В тому ж випадку, коли вони використовуються для вираження цінності, вони отримують символічне значення. Саме 3 цієї позиції випливає те, що коли символ, який є носієм цінності і приналежністю певної культури, інвертується, то саму інверсію можна сприймати лише як контр-традиційне явище, іноді навіть вороже до матерньої ціннісної традиції. Трансформація ж, яка $є$ певним визначенням еволюції символічних форм у більшості випадків відбувається в результаті змін самої культури під впливом часу, політичних, світоглядних чи соціальних змін.

Потребує подальшого дослідження етимологія слова символ. Толковий словник Даля дає таке означення - слово "символ" походить від 


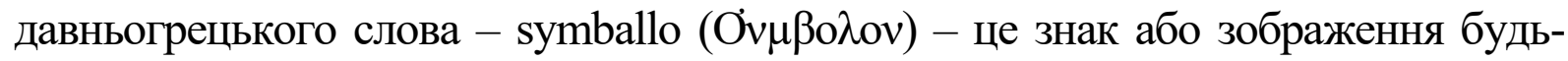
якої речі, або тварини для означення якості предмету; умовний знак будь-яких понять, ідей, явищ.

Не виключена можливість й іншого трактування слова символ. Знак і символ - це перш за все матеріальний предмет, який виступає як об'єктивний замінник деякого іншого предмету, якості чи співвідношення і при цьому використовується для отримання, зберігання та переробки інформації (знань). Це емпірично даний носій образу, органічний із його функціональним призначенням (Культурология. Краткий тематический словарь. Под ред. Г.Драча и Т.Матяш).

Взагалі-то багатозначне вживання слова "символ" ускладнює можливість дати йому загальне визначення, встановити, чим же він відрізняється від інших знаків. На наш погляд, ближче за все до розуміння специфіки символу знаходиться культурно-історична трактовка художніх символів та символів релігійних. Так само, на думку К.Г. Юнга, світ культури пов'язаний з природою людини, а в ній на першому місці "вічні" символи, що знаходять своє втілення в релігійно-міфологічних уявленнях i творах мистецтва [Юнг Карл Густав. Архетип и символ. - М., 1991].

Такі релігійні символи, як християнський хрест чи мусульманський півмісяць, в онтологічній площині мають подвійну природу. 3 одного боку, це графічні знаки, які мали досить широке розповсюдження протягом історії людства в різних часових прошарках та в різних культурах (із різними значеннями). 3 іншого ж боку, вони несуть глибокий духовний зміст, концентрують в собі величезну силу релігійних ідей та глибинних переживань. Символи ці прямо стосуються трансцендентного як найвищої об'єктивної реальності. Аналіз наукової літератури дає змогу звернутися до праці Ю.М. Лотмана "Символ в культурі", де автор визначає можливість двох підходів у вивченні символів - раціонального та ірраціонального. В одному випадку, символ виступає як знак, в іншому - як накопичувач пам'яті культури. Специфіка такого підходу в тому, що символ накопичує значення, в яких раніше виступав, пронизуючи культуру по вертикалі. 3 однієї історичної епохи символ із притаманним йому значенням переходить в іншу, де отримує нове змістове зіставлення і значення, не втрачаючи попередніх. Саме така картина ірраціоналістичного підходу до вивчення феномену повністю відкриває проблему трансформації символу в культурно-історичному процесі.

Символ виступає як механізм пам'яті культури, "як послання інших культурних епох (інших культур), як нагадування про стародавні, вічні основи культури" [Лотман Ю.М. Избран. статьи. В 3-х т. - Т.1. Статьи по семиотике и топологии культуры. - Таллин, 1992. - С. 191-199].

Так, християнський хрест пов'язаний $з$ давно очікуваним приходом на землю Спасителя людського роду. Цей прихід нібито буде супроводжуваться найліпшими рисами характеру людини: вірою, надією і любов'ю. Вірою в те, що Бог, втілившись, став Христом; надією на те, що це втілення відбулося заради людей, заради їхнього спасіння, що Бог $\epsilon$ любов. Хрест, який в очах 
давніх римлян був ганебним знаряддям страти, який в язичницькі часи використовувався в магії (в якій беруть свій початок майже всі символи), стає символом спасіння та вічного життя, жертовної любові Бога до своїх дітей.

У зв'язку з цим, відповіді на звинувачення християнства у запозиченні цього символу ми знаходимо в праці відомих дослідників християнської культури. Так, в Л.А. Успенського читаємо: "Користуючись формами античного мистецтва, вона, (першохристиянська церква) наповнювала їх своїм змістом, від якого змінювалися і самі ці форми" [Успенский Л.А. Иконы Православной Церкви. Первохристианское искусство]. Відтак, церква бере 3 язичницького світу все те, що можна назвати "християнством до Христа". "Символ корабля , - пише дослідник, - у далекій давнині означав подорож душі у потойбічне, а 3 часів появи християнства став просто символом благополучного життєвого шляху та спасіння... Згодом корабель став символом церкви, яка пливе по хвилям житейського моря, а також символом душі, яку веде церква". 3 цього ж приводу Ю. Вороб'євський пише: "До Христової Вісті культи несли в собі ту малу частку Істини, яку могла вмістити тоді давня людина..." [Воробьевский Ю. Шаг змеи. - Яуза, 2005].

Тому, перш ніж звинувачувати релігію в запозиченні символів, треба мати на увазі, що оскільки будь-які символи є важливим механізмом пам'яті культури, то вони й переносять свої значення, онтологічні, релігійні уявлення та інші навантаження із одного пласту культури в інший. 3 міфологічного світобачення символ потрапляє до релігії як на вищий щабель духовних сходинок. Пронизуючи прошарки культури, універсальні символи певною мірою беруть на себе функцію поєднання. Створюючи пам'ять культури про себе, вони не дають їй розпастися на ізольовані хронологічні пласти. 3 іншого ж боку, трансформуючись, вони вбирають в себе "дух" наступних епох. Єдність основних класичних символів, які домінують, i час, протягом якого вони використовуються, саме ці два фактори визначають національні та умовні межі культур. Язичницька доба закінчується, християнство займає домінуючу позицію. Слов'янська культура мала чудовий фундамент, містила в собі вже сформовані моральні цінності та норми, які й стали благодатним підгрунтям для прийняття нової монотеїстичної релігії. Християнство ж створило свій особливий життєвий принцип, свій особливий світогляд, на противагу міфологічному (античному) світогляду. Але цей рішучий розрив, межа, яка розділяе ці дві епохи, ще довго завуальовувалася використанням спільних символів - символів, які були зрозумілі як язичникам, так і християнам.

Тепер спробуємо дати відповідь на питання: чому історично найбільш харизматичні символи характеризуються деякою мірою невизначеності щодо взаємозв'язку "форма - зміст". Частіше форма не завжди повністю відкриває зміст. Можливо, це пов'язано 3 тим, що матеріальна частина не повністю відкриває смислове навантаження, а лише несе незначну частину матеріалізації глибинних ідей, з тим, що матеріальна частина $є$ приналежністю профанічної, відкритої широкому загалу сфери культури, а ідеальна сторона відноситься до сакральної, езотеричної, релігійної таємниці. Так, в буддизмі була створена ціла 
система символів-образів, які позначають прихований зміст вчення Будди і його життя. Найбільш розповсюдженим символом є зображення колеса та сяючого кола, які символізують вчення Будди чи його самого у неантропоморфному варіанті. (сяюче коло, як відомо, $є$ перехідним символом із часів язичницького поклоніння Сонцю, яке дарує світло і життя). В християнстві також була створена ціла низка символів, яка виявляла найосновніші принципи. В "Символі віри" - як в православ'ї, так і в католицизмі - були сформульовані основні засади християнства - його вчення про триєдиного Бога: Бог - Отець, Син та Святий Дух. Це вчення було зашифроване в символах-знаках, для зображення котрих були створені образотворчі аналоги: око, ягня, голуб. Згодом перші два символи трансформувалися, отримавши антропоморфний характер, проте вони продовжували існувати паралельно із первісними варіантами. Озираючись на це, можна зробити висновок, що важливим $є$ те, що змістовні можливості символу завжди ширші за свою дійсну реалізацію: зв'язки, в які вступає символ за допомогою свого змісту із тим чи іншим оточенням, не вичерпують усіх його змістових потужностей. Це й створює простір, в якому символ еволюціонує та трансформується, змінюючи свою сутність і впливаючи іноді навіть на хід історіiі.

Зараз доречно тут згадати те, що дійсно деякі символи існують ще до зміни культурного пласту і незалежно від нього. Але вони потрапляють в пам'ять нової культури із глибин минулого і оживають в новому значенні, тобто трансформуючись отримують нове життя. 3 іншого ж боку, символи активно корелюють із культурним контекстом, трансформуються під його впливом i самі його трансформують. Їх інваріантна сутність реалізується у різних варіантах. Саме в тих змінах, яким піддається "вічне" значення символів в даному культурному контексті, контекст цей яскравіше за все інше виявляє свою змінюваність. Отже, дійсно, теоретичний аналіз символів неможливий без вивчення їх історії. Аналіз символу в системі культури визначає необхідність розгляду його функцій в процесі еволюції людської свідомості та суспільства. Оскільки символ для культури є формою опредметнення та трансляції іï таємних смислів та цінностей, то він стає об'єктом для розшифровки та інтерпретації наступних поколінь. За допомогою символів ми переміщуємося, але не в реальному, а в культурному просторі. Ми спостерігаємо засвідчення того, про що писав Ю. Лотман, а саме: "Символ ніколи не належить до якогонебудь одного синхронного зрізу культури. Він завжди пронизує цей зріз по вертикалі, переходячи із минулого і зникаючи у майбутньому. Пам'ять символу завжди древніша, аніж пам'ять його несимволічного текстового оточення" [Лотман Ю.М. Избран. статьи. В 3-х т. - Т.1. Статьи по семиотитке и теологии культуры. - С. 91-99].

Відтак, сучасна релігійна символіка перейшла до нас з дохристиянських часів і розвинулась разом із поширенням християнства. Л. А. Успенський пише: "Одним із найбільш розповсюджених символів перших віків християнства була риба. Символ цей також запозичений. Прийняттям його християнами звичайно, сприяло те, що риба грає велику роль в євангельських сказаннях. Але ці 
запозичення не змінювали сутності християнства" [Успенский Л.А. Иконы Православной Церкви. Первохристианское искусство]. Чому саме риба слугувала таємним символом християн? Коли в часи гоніння на християн та церкву, іï сповідникам доводилося ховатися від переслідувань в горах та печерах, тоді не можна було відкрито сповідувати Христа, і вірні його послідовники приховували його ім'я під знаком "Риби", бо в літерах грецького

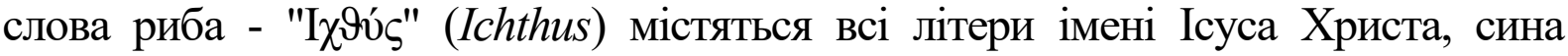
Божого як спасителя світу. Сам же Спаситель неодноразово користувався образом риби та рибалки, називаючи своїх учнів "ловцями людей" (Мт. 4:19; Мк. 1:1). Царство Боже символізувалося ним в образ рибацької сіті сповненої рибою, з рибою ж порівнювалися і всілякі небесні блага (Лк. 5:10).

Означений символ - $\mathrm{i}$ хрест і риба - дає змогу певною мірою тлумачити i розуміти містерію втілення та самопожертви, раціоналізувати ірраціональне. Все це пояснюється любов”ю Бога до людей: "Бог бо так полюбив світ, що дав Сина свого єдинородного, щоб кожен хто вірує в нього, не загинув, але жив життям вічним” (Ів. 3:16). Ця жертва Христа за людей докорінно відрізняється від язичеських жертв, яку приносили, щоб задобрити древніх божків. Вона $\epsilon$ жертвою вищого порядку, бо робиться заради людей, їхнього спасіння та життя вічного. Жертва приноситься не заради смерті того, хто собою жертвує, а заради життя. Вона є найбільшим життєдайним, життєствердним Божим даром.

Трансформація символу із міфологічного світобачення в релігійне відображає зміну основних духовних уявлень на зламі культур. Саме тому, напевно, не коректно і науково не перспективно ставити питання про якісь запозичення. Головним $\epsilon$ те, що народи сповідували різні, але в деякій мірі співзвучні цінності. Саме тому символіка, трансформуючись, поєднала обидві епохи - язичницьку і християнську, ставши "містком" між двома різними культурами. З'ясовуючи, що є добро, що є істина, справедливість тощо, цінності старої та нової епох, які завжди конституюють сенс людського існування, утворюючи його духовну основу, набувають нових рис, обростаючи новими значеннями і втілюються в символіці. I нехай сучасний філософський світогляд відрізняється розмаїттям форм вияву, своєрідність яких зумовлюється розбіжностями у філософських ідеях, поглядах, переконаннях, концепціях і системах, покладених в їх основу, проте, вічні цінності проходять крізь непослідовність і суперечливість сьогодення, плекаючи найкращі почуття людської душі - віру, надію, любов та справедливість. Тому необачне і не виважене використання та тлумачення символів $\epsilon$ неприпустимим 3 точки зору історії та культури. Еклектика в трактовці обумовлена неосвіченістю користувача, веде до спотворення істинного значення та до викривлення історії символу або ж взагалі до втрати його ціннісного характеру. Бо прикро, коли давні символи зазнають викривлення, втрачаючи свій істинний зміст, перетворюючись на безглуздя чи зовсім втрачаючи своє духовне навантаження, адже разом із символом у сучасному світі культура перестає бути тільки цінністю, чимось винятково позитивним, щодо іiі творця - людини. Вона 
починає розглядатись як щось штучне, зовнішнє щодо людини, навіть вороже ії індивідуальній свободі, втаємниченому внутрішньому світу.

\section{Анотації}

У статті М.Яркіної «Світоглядна складова трансформації символів» проаналізовано філософсько-світоглядні аспекти трансцендентної природи символів, які проходять крізь призму історії та культури. Автор статті, звертаючись до дослідження форм та основних фраз формування універсальних символів, вивчає зв'язок між виникненням символу та його подальшим транссрормуванням. Метою статті $\epsilon$ висвітлення, окрім семіотичної та знакової складових символу, саме світоглядної як основної складової в процесі трансфрормації. Автор ставить перед собою завдання визначити момент переходу універсального символу в площині часу із міфологічного у релігійний тип світогляду. Особлива увага приділена проблемі культури та цінностей, відображених в символі. Наголошується на невиправданості твердження про запозичення символів. Окремо акцентується на необхідності виваженого та обачного використання стародавніх символів та знаків.

В статье М.Яркиной «Мировоззренческая составная трансформации символов» проанализированы фрилософско-мировоззренческие аспекты трансцендентной природы символов, проходящих сквозь призму истории и культуры. Автор статьи, обращаясь к исследованиям форм и основных фраз фоормирования универсальных символов, изучает связь между возникновением символа и его дальнейшей трансформацией. Целью статьи является освещение, кроме семиотической и знаковой составляющей, именно мировоззренческой, как основной составляющей в процессе трансформации. Главное внимание уделено проблеме культуры и ценностей, заложенных в символе. Ударение ставится на неоправданности утверждения о заимствовании символов. Отдельно акцентируется на необходимости разумного использования древних символов и знаков.

In the paper explores the philosophical and ideological aspects of the transcendent nature of characters which pass through the prism of history and culture. The author of the article, referring to the study of forms and basic phases forming universal characters, exploring the relationship between the emergence of the character and his subsequent transformation. The aim is to highlight but a semiotic sign and symbol is the ideological component as a major component in the process transformation. The author sets a task to determine the time of transition universal symbol in the plane of time with mythological type of religious belief. Particular attention is paid to the problem of culture and values reflected in the feature. Emphasis is on unjustified allegations of borrowing features. Separately, emphasizes the need for a careful and cautious use of ancient symbols and signs. 